\title{
Policy Model for Sustainable Drinking Water Supply System
}

\author{
Yuki Mahardhito Adhitya Wardhana \\ PT Penjaminan Infrastruktur Indonesia (Persero)
}

Corresponding author:

m.yuki@iigf.co.id

ABSTRACT

In RPJMN 2015-2019, the government has aimed to reach a 100\% drinking water services coverage throughout Indonesia in 2019. The actual proper drinking water coverage until 2015 was still at 67.7\%. This research seeks to formulate a policy model for sustainable drinking water management system. The method of analysis used in this research is the process model method. The results obtained in this study are policy models for sustainable SPAM development that will include the main variables of this system: raw water source, water treatment processes and water distribution.

Keywords: Drinking Water Supply System (SPAM), Sustainability, Drinking Water

\section{SARI PATI}

Pemerintah dalam RPJM 2015-2019 memiliki target cakupan pelayanan air minum di seluruh Indonesia pada tahun 2019 harus sudah mencapai 100\%. Realisasi cakupan pelayanan air minum yang layak sampai dengan tahun 2015 adalah sebesar 67,7 \%. Penelitian ini bertujuan untuk merumuskan model keberlanjutan dari Sistem Pengelolaan air minum. Metode analisis yang digunakan dalam penelitian ini adalah metode model proses. Hasil yang diperoleh dalam penelitian ini adalah Model kebijakan untuk pembangunan SPAM yang berkelanjutan minimal terdiri dari variabel air baku, proses pengolahan air dan distribusi air.

Kata Kunci: SPAM, keberlanjutan, air minum

Copyright (c) 2018, Journal of Infrastructure Policy and Management 


\section{INTRODUCTION}

Water is the most basic necessity of life that is not limited to humans only. Humans need water to drink to replace their body fluids, as well as other animals. Plants require water to complete the photosynthesis process which in the end will produce the oxygen needed by all living things. The importance of water resources underlying the existence of Article 33 paragraph 3 of the Constitution of Indonesia (UUD 1945) which reads the land, the waters and the natural resources within shall be under the powers of the State and shall be used to the greatest benefit of the people. Therefore, the sustainability of water resources is guaranteed by the state.

Water as an irreplaceable environmental component affects and is affected by the other environment elements. Poor quality of water will result in poor environmental conditions that will affect the health and safety of humans and the life of other living beings. Any decrease in water quality will diminish the usability, the productivity and the carrying capacity of water resources that will ultimately reduce the accessibility to natural resources in general.

Water as an important component of natural resources must be used for the greatest prosperity of the people. This means that the use of water for different purposes and interests should be conducted in the wisest manner possible, by taking into account the interests of the present and the future generations. Every human being needs clean water for drinking, for recreation or sometimes for the simple pleasure on the eyes. The basic need for clean water is estimated at 120 liter/person/day (SNI 03-7065-2006, 2016). This clean water need can be fulfilled by water that comes from lakes, rivers and underground water. The national water needs in Indonesia are currently concentrated in Java and Bali, with its primary objective for drinking water and for utilities (for household, urban area, industry, agriculture, and other users). The water balance statistics of 2003 shows that only 25.3 billion cubic of clean water can be provided out of 38.4 billion cubic meters clean water demand on the island of Java and Bali during the dry season or only about 66 percent. This deficit is expected to be even higher by 2020, as population and economic activity are expected to increase significantly. (Directorate of Water System and Irrigation, National Development Agency, 2006). A global study on water conditions in the world, presented at World Water Forum II in Den Haag in 2000 , projected that by 2025 there will be a water crisis in many countries all over the word. Indonesia, being included within the top 10 richest country in water, is expected to suffer this future water shortage as a result of water management errors, reflected by high levels of water pollution, inefficient water use, large fluctuations in river water flow, weak authority in government institutions and inadequate regulations.

The island of Java, which covers up to seven percent of the total land area of Indonesia, has only four and a half percent of the total national freshwater potential, although the island is home to about 65 percent of the total country's population. This condition illustrates the looming potential of water scarcity in this island. Java records its annual water availability number at 1750 cubic meters per capita per year which is still below the health standard at 2000 cubic meters per capita per year. This number is expected to keep declining where only 1,200 cubic meters per capita per year will be available by 2020. If this phenomenon continues, the regional development will be strictly limited due to the exceeded carrying capacity of local water resources (Ministry of PPN / Bappenas, Infrastruktur Indonesia, 2003).

This shortage on water resources, especially drinking water, pushed the government to create policy and strategy in order to achieve its medium-term development plan (RPJM) 
target on the drinking water service coverage throughout Indonesia which should reach 100\% by 2019. This target will never be achieved if the strategy only focuses on the service aspect without considering the capacity of the water resources. Hence this research on the policy model for sustainable drinking water supply system.

\section{Objective and Scope of Research}

The objective of this research on the Policy Model for Sustainable Drinking Water Supply System is self-explanatory: to formulate a sustainable model of drinking water management system. The scope of this research will cover drinking water supply systems that use surface water for its raw water source.

\section{Literature Review}

Drinking Water Supply System (Sistem Penyediaan Air Minum or SPAM)

The Government Regulation (PP) no.122/2015 defines Drinking Water Supply System/SPAM as integrated facilities and infrastructure of drinking water supply. SPAM is develop to provide drinking water services to the community to meet the right of people for potable water. Drinking water supply system is established with the following objectives:

1. Providing drinking water services as the basic right of people.

2. Establishing a quality drinking water management and service at an affordable price.

3. Achieving the balanced interests between customers and BUMNs, BUMDs, UPTs, UPTDs, Community Groups, and other Business Entities.

4. Developing effective and efficient drinking water system to expand the coverage of this services
The use of water resources used to refer to Law no. 7/2004 on Water Resources, but the Decision of the Constitutional Court no.85/PUU-XI/2013, released on February $18^{\text {th }}$ 2015, has annulled the aforementioned law and therefore has reenacted Law no. 11/ 1974 on Water System. This decision of Constitutional Court mentioned several restrictions on the implementation of drinking water supply system as follows:

1. Any water source exploitation shall not restrict, put aside, nor abolish the people's right to water as land, water and all natural resources in the country shall be controlled by the state, also the use these resources shall be designated for the greatest prosperity of the people.

2. The state shall fulfill the people's right to water. Access to water is one of the basic human rights, and the Article 28I, paragraph (4) of the Constitution states that the protection, promotion, enforcement, and fulfillment of human rights is the responsibility of the state, more specifically the government

3. The preservation of the environment is considered as one of human rights. The article $28 \mathrm{H}$ paragraph (1) of the Constitution states that every person has the right to live in physical and spiritual prosperity, to reside and to get a suitable and healthy environment and is entitled to receive health services.

4. Drinking water supply system is an important branch of production which affects the life quality of the people and therefore must be controlled by the state. It is stated in the article 33 paragraph (3) of the Constitution that water resource must be controlled by the state and must be used for the greatest prosperity of the people. Consequently the state control over it is absolute. 
5. As the extension of the state control over the water resource and considering that water is vital to the public, the state-owned enterprises (BUMN or BUMD) are given the priority to run the water exploitation industry.

6. If all the conditions above have been fulfilled and there is still other water resource available, the Government is allowed to grant permission to private entities to conduct water supply business with certain conditions and restriction.

These restrictions in the Decision of Constitutional Court are further elaborated in Government Regulation no.121/2015 on Water Resources Management and Government Regulation no.122/2015 on Drinking Water Supply System.

The components of the drinking water supply system are generally as follows (Triatmadja, 2009):

1. Water source and broncaptering (water catchment installation from the water source).

2. Water Treatment Installation which is integrated facilities that process raw water into filtered water or potable water.

3. Reservoir.

4. Transmission Pipe.

5. Distribution Pipe.

6. Pump, which is defined as machines used to transport liquids from one place to another through a continuous pipe medium by increasing the energy in the transported liquid.

7. Pressure Release Tank is a supporting part on transmission or distribution network that serves to remove excessive pressure on the flow that may cause the pipe to break.

8. Valves

9. Volume Gauge or Flowmeter is a device to measure the amount or flow rate of a fluid flowing in a pipe or in an open channel.

\section{Sustainability}

Sustainable development is defined as a development that meets the present needs without compromising the ability of future generations to meet their own needs (WCED, 1987). Meanwhile, Green and Szabalcs (1994), states that the future needs will depend on the interlinking relationship between population growth, energy resource management and environmental protection.

Sustainable development requires the basic human needs to be fulfilled for a better and more decent living. Livelihoods consist of capacities, assets (reserves, resources, ownership and access) and activities needed for living facilities or for meeting basic human needs (Chambers and Conway, 1991). To meet the quality of their basic needs, humans need the environment. The degree and quality of the fulfillment of basic human needs is closely related to the quality of the environment. The more basic needs are met, the better the quality of life (Soemarwoto, 2004).

Fauzi and Anna (2005) state that the concept of sustainable resource development contains the following aspects:

1. Ecological sustainability. In this view, the utilization of forest resources should not exceed the limits of their carrying capacity. Increasing the capacity and quality of the ecosystem shall be the priority.

2. Socioeconomic sustainability. This concept implies that forestry development shall take into account the sustainability of the prosperity of the forest resource users at the individual level.

3. Community sustainability refers to the sustainability of the community welfare that should be considered in a sustainable forestry development.

4. Institutional sustainability. Within this 
framework, institutional sustainability portrays a healthy financial and administrative aspects which are prerequisites of the three sustainable development aspects above.

There are four principles of natural resource management that shall be applied to achieve sustainable development:

a. Optimizing socio-economic utilization. The development of natural resources should be based on strategies that can optimize the long-term socio-economic benefits of renewable natural resources.

b. Coordination among sectoral areas. Natural resource ecosystems must be managed by integrating sectoral policies, planning and management strategies in order to optimize their utilization. The optimization of socio-economic benefits can be achieved by improving coordination in the planning process over the needs for natural resource.

c. Multipurpose natural resources. To optimize these resources' utilization, natural resource planning and management activities are undertaken to profit from the various uses of existing and renewable natural resources.

d. Attention to the ecosystem capacity. The exploitation of natural resources will depend heavily on the ability of the natural resource ecosystem to provide these resources to meet the demand.

\section{Model}

A model is an abstraction of the actual system, in a simpler image and has a more overall percentage rate. A model can be seen as an abstraction of reality by focusing on some traits of real life (Simamarta, 1983). There are four commonly used models as follows:

1. Physical Model. This model is the entities representation in a three dimensional form. Physical model is normally smaller than the real thing and is usually used in the business to showcase a new model prototype.
Physical models help to attain an objective that cannot be fulfilled using the real object. For example, shopping center investors and car makers can make a number of changes much cheaper through the design of the offered physical model which is comparable to the final product.

2. Narrative Model. This model portrays the entity orally or in writing. All business communication is a narrative model, so the narrative model is the most popular and most commonly used model in management.

3. Graphical Model. This type of model represents the entities using lines, symbols, shapes, and with little narrative explanation, e.g. financial reports with colorful graphs to clarify the content in discussion.

Mathematical Model. This model is presented with a mathematical formula or equation. This model is often used by management for business activities, or for prediction, analysis and others which requires a model with high accuracy. However this model is often not preferred due to its complexity.

\section{METHODS}

The method used to develop the Policy Model for Sustainable Drinking Water Supply System is the process model method. According to Dunn $(1994$,$) a process model is a policy formulation$ that includes a series of activities which lead to the evaluation of public policy. The flow diagram for this research on Policy Model for Sustainable drinking water supply system is presented in Figure 1.

The following steps are taken in formulating a policy model for sustainable drinking water supply system:

1. Problem identification

The problem identification is done by clustering the business ecosystem of drinking 
water supply process (water source, water treatment process and distribution). The problems are identified by the researcher's analysis on the business development process at SPAM X and SPAM Y.

\section{Policy formulation}

Based on the results of problem identification, a Clausal Loop Diagram (CLD) model will be formulated as the basis for policy formulation. The policy is prepared by providing a workable solution to the existing gap on problem identification.

4. Validation of policy implementation The validation of the policy model for sustainable water supply system is conducted through compatibility tests with the sustainability development parameters.

This research was conducted in period of July-November 2017. The sample used in this research was from SPAM X and SPAM Y which were still on development process. The data used are primary and secondary data. Primary data consist of observation and discussion to stakeholders of SPAM X and SPAM Y, while secondary data come from report or study related to SPAM X and SPAM Y. Data were retrieved by triangulation method which consists of:

1. Desk study, which is the collection, study, analysis of data available on documents that are considered valid and traceable.

2. Interview, by conducting interviews with certain individuals or personnel who have capabilities in their field.

3. Observation, by making observations, recordings, collecting quotes and tracing the validity of the data.

\section{Limitations of Research}

This research is limited in terms of the variables used in business ecosystem cluster of water supply process, where only the variables with dominant influence are selected, while the nondominant variable are ignored.

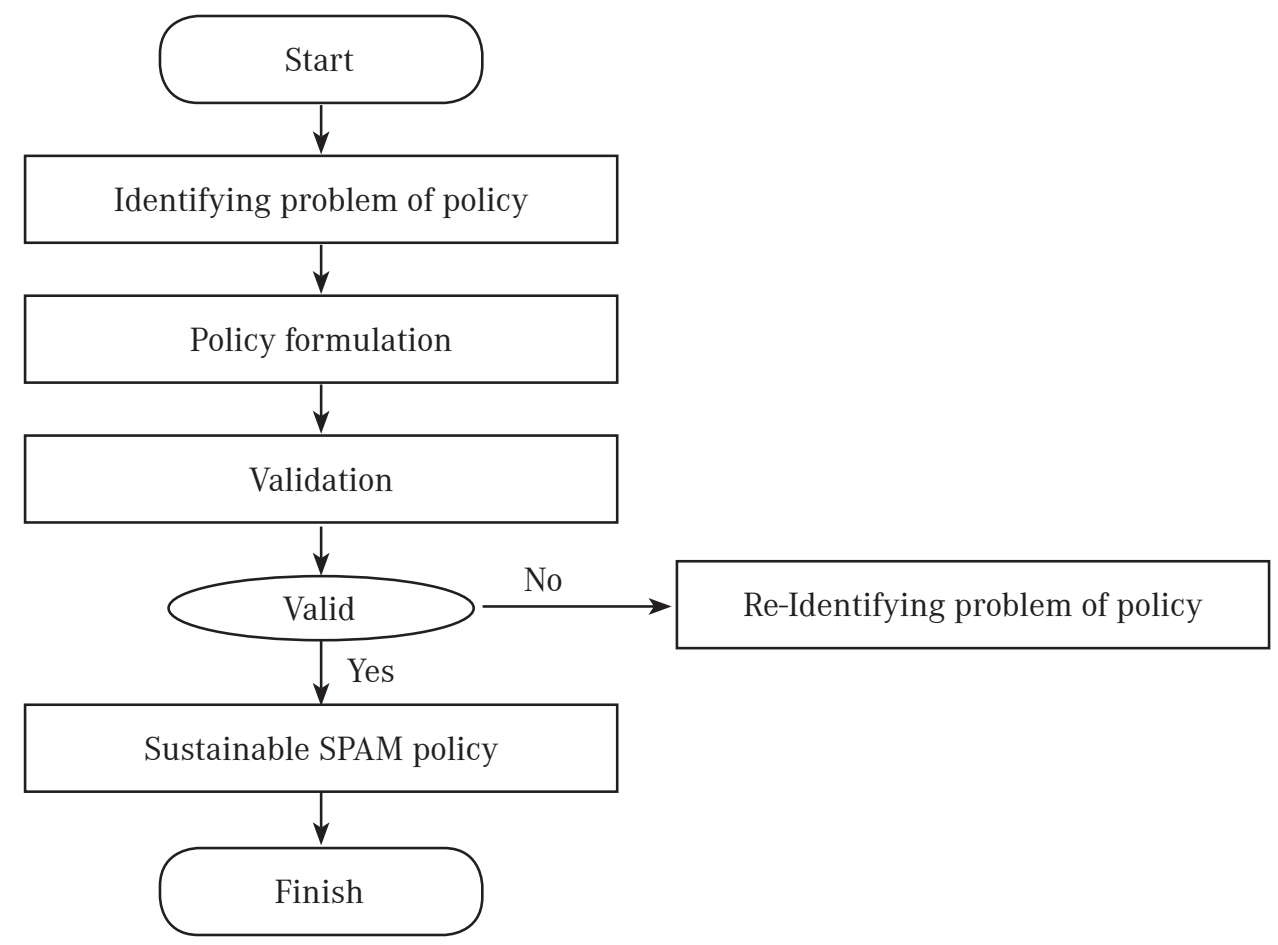

Figure 1. Flow diagram of research method on Policy Model for Sustainable drinking water supply system 


\section{RESULT AND DISCUSSION}

\section{Problem Identification}

The problem identification in the business process of water supply industry can be divided into three parts:

\section{Raw water resources}

Based on the analysis, discussion and observation result on the development preparation process of SPAM X and Y, the following information was obtained related to raw water sources:

a. The capacity of raw water source will determine the maximum production or water volume capacity per day, therefore the quality, quantity and continuity of river water are crucial. Water quality is strongly influenced by the existing activities in the watershed, the condition of the catchment area and the river itself. The influential stakeholders for the quality of water are the Ministry of Environment and Forestry and the Local Government. The quantity and continuity of river water are affected by the weather and the characteristics of the river water source which comes from natural springs or reservoirs. Stakeholders that influence these element are the Ministry of Public Works and People's Housing and the Local Government.

b. One of the key points of the Decision of the Constitutional Court no. 85/PUU-XI/2013 is that the state control can be extended and since water is deemed vital for livelihood of the people, state-owned enterprises (BUMN or BUMD) are therefore given the priorities for water provision business.

Looking at the two explanations above, there is a gap that is, on one side BUMN or BUMD is assigned to be the drinking water provider for public, but on the other hand BUMN or BUMD has no authority to affect the quality, quantity and continuity of raw water, although according to Article 48 letter (f) of PP no.122/2015, BUMN and BUMD are obliged to participate in efforts to protect and conserve water resources in the context of conservation of environmental functions. This may impose a high risk for BUMN or BUMD: for example let say at the moment, a BUMN or BUMD is developing a water supply system with a raw water processing capacity at 1000 liter/second considering the current river carrying capacity at this time. However within 10 years, we may expect some headwater areas conversion taking place as the consequence of changes in the spatial plan and this will affect the quality, quantity and continuity of water source. This conditions will surely disrupt the sustainability of the drinking water supply system due to the lack of volume and the poor quality of raw water, resulting in increased OPEX and rising water tariff which will be no longer affordable by the community.

\section{Water treatment process}

Based on the results of the analysis, discussion and observation on the development preparation process of SPAM X and Y, the researchers found information related to the water treatment process shown by the river water test data as stated in the feasibility study of SPAM X and SPAM Y. The data show that there are severa parameters that exceed the quality standard which may bring the following effects:

a. Any increase in one of the raw water parameters will result in the increase in OPEX for raw water treatment. For example: according to the pre-feasibility study report of SPAM X, for every liter of river water contaminated with 1 milligram of BOD (Biological Oxygen Demand), the cost of processing into potable water will increase by IDR 9.14 per liter. This cost of water quality normalization will be directly transferred to the customers of Regional Water Supply Companies (Perusahaan Daerah Air Minum or PDAM). This figure is equivalent to $25 \%$ of the final tariff imposed by PDAM, or in other words for every monthly PDAM bill of IDR 100,000 paid by a household customer, 25\% of this 
bill is allocated to treat the contaminated water source of PDAM.

b. Any increase in one of the raw water parameters will result in the increased OPEX for waste treatment. For example a high level of TDS and TSS will potentially increase the sludge production from raw water treatment process. This translates as more cost for sludge disposal.

\section{Water Distribution}

One crucial factor in water distribution is the rate of water loss or often called Non-Revenue Water (NRW). Based on the analysis on the level of water loss in SPAM X and SPAM Y stated in the pre-feasibility study report, the average rate of water loss from both entities is above $50 \%$. According to the Directorate General of Human Settlements (2016), the national NRW rate reached $33 \%$, which is a very high figure. This high level of NRW is due to the damage on distribution pipelines and illegal connecting.
High NRW rate will lead to the loss of potential revenue and will ultimately disrupt the company's cash flow.

\section{Policy formulation}

The policy formulation will be developed based on the CLD model. The CLD model is based on problem identification, and for this research the model can be illustrated as shown in in Figure 2 .

The Clausal Loop Diagram (CLD) policy model on sustainable drinking water supply system consists of six positive loops. The positive loop shows a mutually reinforcing relationship, in the sense that a stronger influencing factor will make the influenced factor stronger as well. The high number of positive loops shows that all the variables have a significant influence. It can also be seen that the whole loop (from R1 to R6) forms a closed loop meaning that in drinking water supply system business, all of its variables strongly affect each other.

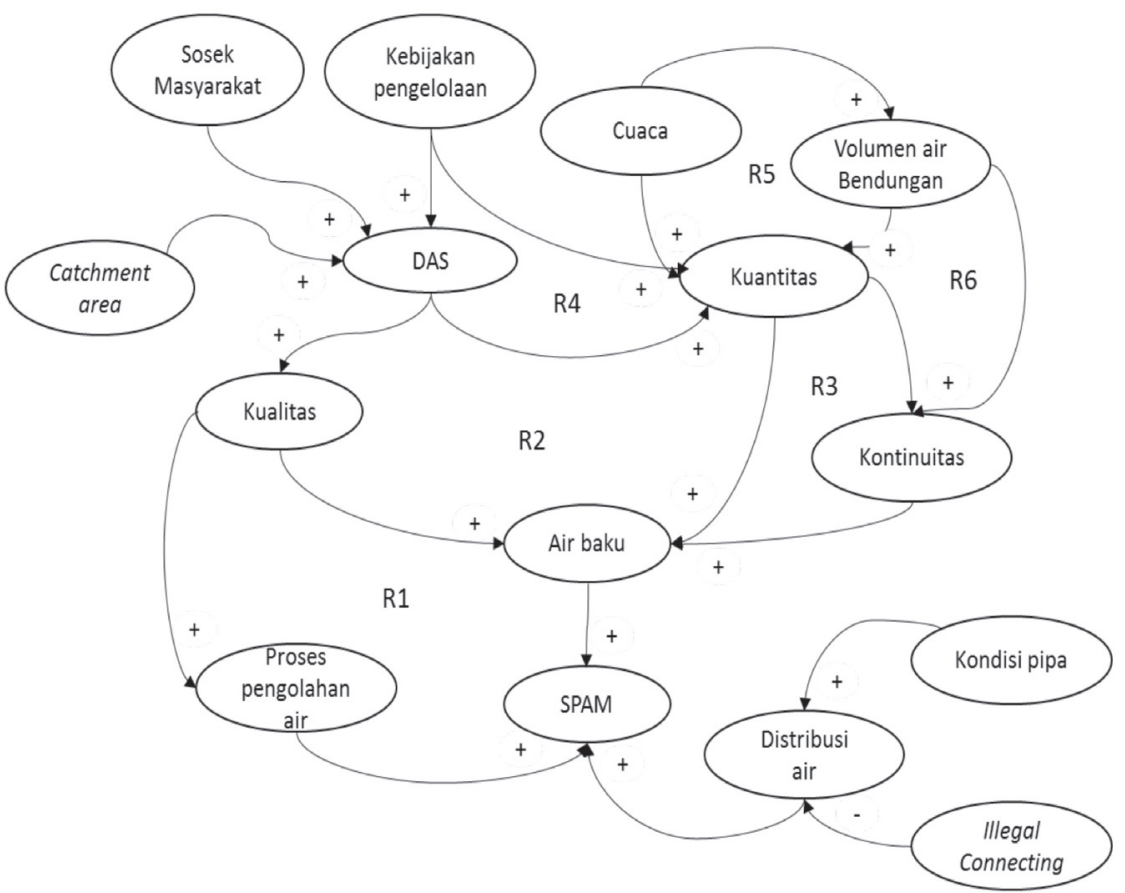

Figure 2. Clausal Loop Diagram (CLD) policy model on sustainable drinking water supply system 


\section{Policy Model}

The type of model used for this research is the narrative model. This model describes the entity orally or in writing and is the most popular and most commonly used by various stakeholders as all business communication is basically a narrative model. The CLD model as shown in Figure 2 is the basis for creating the policy model for sustainable drinking water supply system. The policy model can be described as follows:

1. Based on the CLD big loop, one of the most important factors that can determine the sustainability variables, including raw water, is the watershed management policies. Watershed management policies may affect the quality, quantity and continuity of raw water. Based on the analysis, the policy shall ensure that BUMN or BUMD which run the drinking water supply system must be involved in the water catchment area management and must participate in the management of watershed area. Since this drinking water supply system project has a characteristic of a social project, the form of engagement needs consider its financial capability

2. Policies that need to be taken into account to determine whether or not a drinking water supply system project is feasible must be based on the following variables

a. Raw water variable, which includes water quality (influenced by watershed condition, management policies, catchment area condition and socioeconomic conditions of the community), water quantity (influenced by watershed condition, weather and existing water volume in the reservoir) and water continuity (influenced by quantity and existing water volume in the reservoir).

b. Water treatment process which depends on the water quality, determined by various factors such as watershed condition, management policy, condition of catchment area and socioeconomic condition of society

c. Water distribution which covers the existing pipeline condition and illegal connecting situation.

\section{Validation of Policy Model}

The policy model for sustainable drinking water supply system (SPAM) can be considered valid if the model meets the sustainability aspects in the context of economy, environment and social. The validation tool of this research can be further explained in Table 1.

Based on the validation results of the policy model for sustainable drinking water supply system in Table 1, we find that all aspects of sustainability have been met by all variables and sub-variables thus the model is deemed valid as a model of sustainability.

\section{CONCLUSION}

The policy model for sustainable drinking water supply system development at the very least is influenced by the following variables: raw water resource, water treatment process and water distribution. 
Table 1. Validation tool on policy model for sustainable drinking water supply system

\begin{tabular}{|c|c|c|c|c|c|c|}
\hline \multirow[t]{2}{*}{ No } & \multirow[t]{2}{*}{ Variable } & \multirow{2}{*}{ Sub Variable } & \multirow{2}{*}{$\begin{array}{l}\text { Factors on } \\
\text { Sub Variable }\end{array}$} & \multicolumn{3}{|c|}{ Sustainability Aspect } \\
\hline & & & & Economy & Environment & Social \\
\hline \multirow[t]{9}{*}{1.} & \multirow[t]{9}{*}{ Raw Water } & \multirow[t]{4}{*}{ 1.1. Quality } & $\begin{array}{l}\text { Watershed } \\
\text { condition }\end{array}$ & & $\sqrt{ }$ & \\
\hline & & & Management Policy & $\sqrt{ }$ & $\sqrt{ }$ & $\sqrt{ }$ \\
\hline & & & $\begin{array}{l}\text { Catchment area } \\
\text { condition }\end{array}$ & & $\sqrt{ }$ & \\
\hline & & & $\begin{array}{l}\text { Socioeconomic } \\
\text { condition of } \\
\text { community }\end{array}$ & $\sqrt{ }$ & & $\sqrt{ }$ \\
\hline & & \multirow[t]{3}{*}{ 1.2. Quantity } & $\begin{array}{l}\text { Watershed } \\
\text { condition }\end{array}$ & & $\sqrt{ }$ & \\
\hline & & & Weather & & $\sqrt{ }$ & \\
\hline & & & $\begin{array}{l}\text { Existing water } \\
\text { volume in reservoir }\end{array}$ & & $\sqrt{ }$ & \\
\hline & & \multirow[t]{2}{*}{ 1.3. Continuity } & Quantity & & $\sqrt{ }$ & \\
\hline & & & $\begin{array}{l}\text { Existing water } \\
\text { volume in reservoir }\end{array}$ & $\sqrt{ }$ & $\sqrt{ }$ & \\
\hline \multirow[t]{4}{*}{2.} & \multirow{4}{*}{$\begin{array}{l}\text { Water } \\
\text { treatment } \\
\text { process }\end{array}$} & \multirow[t]{4}{*}{ 2.1. Quality } & $\begin{array}{l}\text { Watershed } \\
\text { condition }\end{array}$ & & $\sqrt{ }$ & \\
\hline & & & Management Policy & $\sqrt{ }$ & $\sqrt{ }$ & $\sqrt{ }$ \\
\hline & & & $\begin{array}{l}\text { Catchment area } \\
\text { condition }\end{array}$ & & $\sqrt{ }$ & \\
\hline & & & $\begin{array}{l}\text { Socioeconomic } \\
\text { condition of } \\
\text { community }\end{array}$ & $\sqrt{ }$ & & $\sqrt{ }$ \\
\hline \multirow[t]{2}{*}{3} & $\begin{array}{l}\text { Water } \\
\text { Distribution }\end{array}$ & $\begin{array}{l}\text { 3.1. Existing } \\
\text { pipeline } \\
\text { condition }\end{array}$ & - & $\sqrt{ }$ & & \\
\hline & & $\begin{array}{l}\text { 3.2. Illegal } \\
\text { Connecting }\end{array}$ & - & $\sqrt{ }$ & & \\
\hline
\end{tabular}


REFERENCES

Badan Standar Nasional (National Standardization Agency of Indonesia). 2006. SNI 03-7065-2006. Jakarta.

Chambers, R and Conway, R, G. (1991). Sustainable Rural Livelihoods: Practical Concept for the $21^{\text {st }}$ Century. IDS. Institute Development Studies.

Direktorat Jenderal Cipta Karya (Directorate General of Human Settlements within the Ministry of Public Works). 2016. Infrastructure of Sustainable Drinking Water System. Presented in the scientific environmental forum of HCD $35^{\text {th }}$ PSIL UI, November 19th 2017. http://sil.ui.ac.id/bahan-pembicara/direktur-pengembangan-sistem-penyediaan-air-minum/. Depok.

Dunn, W. (2000). Public Policy Analysis: an Introduction (translated version by Darwin, M.,). Yogyakarta: Gadjah Mada University Press.

Green, D.J., \& Szabalcs. (1992). Soil Resilience and Sustainable Land Use, Proceedings of a Symposium Held in Budapest. Budapest: Research Institute for Soil Science and Agricultural Chemistry Hungarian Academy of Science.

Direktorat Pengairan dan Irigasi Bappenas (Directorate of Water System and Irrigation, National Development Planning Agency). (2006). Final Report Book 1: Strategic Planning on Water Resource Management in Mitigating Flood and Dry spell in Island of Java (in Bahasa Indonesia only). Jakarta: Direktorat Pengairan dan Irigasi Bappenas.

Fauzi, A., \& Anna, S. (2005). Modeling of Fisheries and Ocean Resources for Policy Analysis (in Bahasa Indonesia only) Jakarta: Gramedia Pustaka

Kementerian PPN/Bappenas (Ministry of National Development Planning/National Development Planning Agency) (2003). Infrastructure of Indonesia (in Bahasa Indonesia Only). Jakarta: Kementerian PPN/Bappenas.

Peraturan Pemerintah/PP (Government Regulation) no. 122/2015 on Water Supply System. Jakarta.

Putusan Mahkamah Konstitusi (Decision of Constitutional Court) no. 85/PUU-XI/2013. 2013 on Review on Law no. 7/2004 on Water Resources. Jakarta.

Simarmata, Dj.A. 1983. Operation Research: An Introduction (in Bahasa Indonesia Only), PT. Gramedia Jakarta.

Soemarwoto, O. (2004). Ecology, Environment and Development (in Bahasa Indonesia Only). Penerbit Djambatan. Jakarta.

Triatmadja, R. 2009. Hydraulics and Water Piping Networks (in Bahasa Indonesia Only). Beta Offset, Yogyakarta.

World Commission on Environment and Development. (1987). Our Common Future. Jakarta: PT Gramedia. 